\title{
Hydrogenated fat intake during pregnancy and lactation caused increase in TRAF- 6 and reduced AdipoR1 in white adipose tissue, but not in muscle of 21 days old offspring rats
}

\author{
Juliana L de Oliveira', Lila M Oyama', Ana Cláudia L Hachul', Carolina Biz', Eliane B Ribeiro',
} Claudia M Oller do Nascimento ${ }^{1 *}$, Luciana P Pisani ${ }^{2}$

\begin{abstract}
Background: Although lipids transfer through placenta is very limited, modification in dietary fatty acids can lead to implications in fetal and postnatal development. Trans fatty acid (TFA) intake during gestation and lactation have been reported to promote dyslipidemia and increase in pro- inflammatory adipokines in offspring. The aim of this study was to evaluate whether the alterations on pro-inflammatory cytokines and dyslipidemia observed previously in 21-d-old offspring of rats fed a diet containing hydrogenated vegetable fat during gestation and lactation were related to alterations in TLR-4, TRAF- 6 and adipo-R1 receptor in white adipose tissue and muscle. On the first day of gestation, rats were randomly divided into two groups: (C) received a control diet, and (T) received a diet enriched with hydrogenated vegetable fat, rich in trans fatty acids. The diets were maintained throughout gestation and lactation. Each mother was given eight male pups. On the 21st day of life the offspring were killed. Blood, soleus and extensor digital longus (EDL) muscles, and retroperitoneal (RET) white adipose tissue were collected.
\end{abstract}

Results: 21-d-old of T rats had higher serum triacylglycerols, cholesterol, and insulin. The Adipo R1 protein expression was lower in RET and higher in EDL of T group than C. TLR-4 protein content in all studied tissues were similar between groups, the same was verified in TRAF-6 protein expression in soleus and EDL. However, TRAF- 6 protein expression in RET was higher in $T$ than $C$.

Conclusion: These results demonstrated that maternal ingestion of hydrogenated vegetable fat rich in TFAs during gestation and lactation decrease in Adipo R1 protein expression and increase in TRAF-6 protein expression in retroperitoneal adipose tissue, but not in skeletal muscle, which could contributed for hyperinsulinemia and dyslipidemia observed in their 21-d-old offspring.

\section{Introduction}

Inadequate maternal nutrition during gestation and/or lactation can alter aspects of morphological and physiological development of pups, increasing the predisposition on the adult life to metabolic diseases, like diabetes mellitus and cardiovascular disease [1-3]. Fetal nutrition depends on the concentration of nutrients in maternal

\footnotetext{
* Correspondence: claudia.oller@unifesp.br

'Departamento Fisiologia, Disciplina de Fisiologia da Nutrição, Universidade Federal de São Paulo, São Paulo, SP, Brasil

Full list of author information is available at the end of the article
}

bloodstream, placental perfusion, and transfer of these nutrients through placenta [4-6].

During gestation, changes in the maternal metabolism occur in order to supply nutrition to the fetus. Lipids play a fundamental role in fetal development. Although lipids transfer through placenta is very limited, changes in dietary fatty acids can lead to implications in fetal and postnatal development [7].

Several studies verified that consumption of high amounts of trans fatty acid (TFA) increases blood total cholesterol, VLDL, LDL-cholesterol and triglycerides, and decreases blood HDL-cholesterol, which as consequence

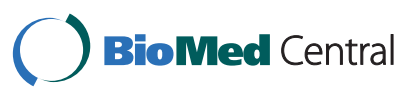

(c) 2011 de Oliveira et al; licensee BioMed Central Ltd. This is an Open Access article distributed under the terms of the Creative Commons Attribution License (http://creativecommons.org/licenses/by/2.0), which permits unrestricted use, distribution, and reproduction in any medium, provided the original work is properly cited. 
increases the chances of development of metabolic syndrome. Also, [8] demonstrated that treatment with TFA has a much greater effect in decreasing adipocyte insulin sensitivity than treatment with saturated fatty acids. The authors explained these results in part by a reduction of plasma membrane fluidity in the rats treated with TFA.

In these sense, we have previously showed dyslipidemia and increased body fat, high TNF- $\alpha$ and PAI-1 mRNA levels, and low plasma and mRNA adiponectin levels in 21-d-old offspring of rats fed a diet containing hydrogenated vegetable fat during gestation and lactation [9].

Insulin resistance and type 2 diabetes mellitus, obesity and heart disease $[10,11]$ have been associated with decrease in adiponectin serum levels. Several studies have been demonstrated that adiponectin reduces hepatic production of glucose and the concentration of triglycerides in the muscles, thus ameliorating insulin sensitivity [12].

Additionally, TFA in the diet was found to increase the production of pro-inflammatory cytokines, like IL-6 and TNF- $\alpha$ [13-20]. These increase could be regulated by Toll-like receptor 4 (TLR-4) signaling, which stimulates inflammatory cytokine production [21].

Toll-like receptors (TLR) are trans-membrane proteins that play an important role in recognizing microbial pathogens and mediating whole body inflammation [22]. Tsukumo et al [23] demonstrated that $\mathrm{C} 3 \mathrm{H} / \mathrm{HeJ}$ mice, which have a loss-of-function mutation in TLR4, did not develop obesity and insulin resistance induced by high fat diet. TLR4 is a subclass of TLRs that can be activated by lipopolysaccharide (LPS) and by nonbacterial agonists, such as saturated fatty acids $[24,25]$. The activation of TLR4 signaling induces upregulation of intracellular inflammatory pathways related to the induction of insulin resistance, each included the adaptor molecule myeloid differentiation primary-response protein 88 (Myd88), IL$1 \mathrm{R}$-associated kinases (IRAKs), transforming growth factor- $\beta$ (TGF- $\beta$-) activated kinase (TAK1), TAK-1 binding protein (TAB1 and 2), and tumor necrosis factor (TNF)receptor-associated-factor-6 (TRAF-6) [26,27].

The aim of this study was to evaluate whether the alterations on pro-inflammatory cytokines and dyslipidemia observed previously in 21-d-old offspring of rats fed a diet containing hydrogenated vegetable fat during gestation and lactation were related to alterations in TLR-4, TRAF- 6 and adipo-R1 receptor in white adipose tissue and muscle.

\section{Materials and methods}

\section{Animals and treatments}

The experimental research committee of the Universidade Federal de São Paulo approved all procedures for the care of the animals used in this study. Rats were kept under controlled conditions of light (12-h light/12-h dark cycle with lights on at $0700 \mathrm{~h})$ and temperature $\left(24 \pm 1^{\circ}\right.$ C). Three-month-old female Wistar rats were left overnight to mate, and copulation was verified the following morning by the presence of sperm in vaginal smears. On the first day of gestation, rats were isolated in individual cages and randomly divided into two groups, receiving a control diet ( $\mathrm{C}$ diet, $\mathrm{C}$ group) or a diet enriched with hydrogenated vegetable fat ( $\mathrm{T}$ diet, $\mathrm{T}$ group). The diets were maintained throughout gestation and lactation. On the day of delivery, considered day 0 of lactation, litters were adjusted to eight pups each. The pups were weighed at 21 of lactation, when they were killed.

Both diets were prepared according to the recommendations of the American Institute of Nutrition (AIN93G) [28] being similar in calories and lipid content. The source of lipids for the $C$ diet was soybean oil, and the principal source for the $\mathrm{T}$ diet was partially hydrogenated vegetable fat, rich in TFAs. The centesimal composition of the diets is presented in Table 1 . The fatty acid profile of each diet, was previously described by Pisani et al [9].

\section{Experimental procedures}

After $21 \mathrm{~d}$ of lactation, the offspring were decapitated. Trunk blood was collected and immediately centrifuged. Serum was separated and stored at $-70^{\circ} \mathrm{C}$ for later determination of triacylglycerols, cholesterol, HDL- cholesterol, glucose, insulin and adiponectin. The retroperitoneal (RET) white adipose tissue, soleus and extensor digital longus (EDL) were dissected, immediately frozen in liquid nitrogen, stored at $-70^{\circ} \mathrm{C}$, and used for quantification of TLR4, TRAF6 and AdipoR1 mRNA and protein expression.

\section{Carcass lipid and protein content}

Other groups of $\mathrm{C}$ and $\mathrm{T}$ rats were used for determination of carcass lipid and protein content. Carcasses were eviscerated, weighed, and stored at $-20^{\circ} \mathrm{C}$. Lipid content was measured as described by Stansbie et al. and standardized using the method described by Oller do Nascimento and Williamson, 1986 [29]. Briefly, the eviscerated carcass was autoclaved at $120^{\circ} \mathrm{C}$ for $90 \mathrm{~min}$ and homogenized with double the mass of water. Triplicate aliquots of this homogenate were weighed and digested in $3 \mathrm{~mL}$ of $30 \% \mathrm{KOH}$ and $3 \mathrm{~mL}$ of ethanol for $\geq 2 \mathrm{~h}$ at $70^{\circ} \mathrm{C}$ in capped tubes. After cooling, $2 \mathrm{~mL}$ of $12 \mathrm{~N} \mathrm{H}_{2} \mathrm{SO}_{4}$ was added and the sample washed three times with petroleum ether for lipid extraction. Results are expressed as grams of lipid per $100 \mathrm{~g}$ of carcass. For protein measurements, aliquots of the same homogenate (approximately $1 \mathrm{~g}$ ) were heated to $37^{\circ} \mathrm{C}$ for $1 \mathrm{~h}$ in $0.6 \mathrm{~N} \mathrm{KOH}$ with constant shaking. After clarification by centrifugation, protein content was measured according to the method described by Lowry et al [30]. 
Table 1 Composition of control and TFA-enriched diets according to AIN-93

\begin{tabular}{|c|c|c|}
\hline Ingredient & Diet $(g$ & \\
\hline & $\mathrm{C}$ & $\mathrm{T}$ \\
\hline Casein* & 20 & 20 \\
\hline L-cystine $^{\dagger}$ & 0.3 & 0.3 \\
\hline Cornstarch $^{\dagger}$ & 62 & 62 \\
\hline Soybean oil ${ }^{\ddagger}$ & 8 & 1 \\
\hline Hydrogenated vegetable fat $^{\S}$ & - & 7 \\
\hline Butyl hydroquinone $^{\dagger}$ & 0.0014 & 0.0014 \\
\hline Mineral mixture & 3.5 & 3.5 \\
\hline Vitamin mixture" & 1.0 & 1.0 \\
\hline Cellulose $^{\dagger}$ & 5.0 & 5.0 \\
\hline Choline bitartrate $^{\dagger}$ & 0.25 & 0.25 \\
\hline Energy (kcal/g) & 4.0 & 4.0 \\
\hline
\end{tabular}

C, control; T, hydrogenated vegetable fat; TFA, trans-fatty acid.

* Casein was obtained from CoperLab, São Paulo, Brazil.

' L-cystine, cornstarch, butyl hydroquinone, cellulose and choline bitartrate were obtained from Viafarma, São Paulo, Brazil.

‡ Oil was supplied from soybean (Lisa/Ind. Brazil).

${ }^{\S}$ Hydrogenated vegetable fat was supplied from Unilever, São Paulo, Brazil. || Mineral mix provided (mg/kg) calcium 5000, phosphorus 1561, potassium 3600 , sodium 1019 , chloride 1571 , sulfur 300 , magnesium 507 , iron 35 , copper 6.0 , manganese 10.0 , zinc 30.0 , chromium 1.0 , iodine 0.2 , selenium 0.15 , fluoride 1.00 , boron 0.50 , molybdenum 0.15 , silicon 5.0 , nickel 0.5 , lithium 0.1 , vanadium 0.1 (AIN-93G mineral mix DYETS 210025, Dyets Inc., Bethlehem, PA, USA).

" Vitamin mix (mg/kg diet) provided thiamin HCL 6.0, riboflavin 6.0, pyridoxine $\mathrm{HCL} 7.0$, niacin 30.0, calcium pantothenate 16.0, folic acid 2.0, biotin 0.2, vitamin B12 25.0, vitamin A palmitate $4000 \mathrm{IU}$, vitamin E acetate 75, vitamin D3 1000 IU, vitamin KI 0.75 (AIN-93G, vitamin mix, DYETS 310025, Dyets Inc.)

\section{Biochemical and hormonal serum analyses}

Glucose, triacylglycerols, total cholesterol, and HDLcholesterol serum concentrations were measured by an enzymatic colorimetric method using commercial kits (Labtest, Brazil). Insulin and adiponectin concentrations were quantified using specific enzyme-linked immunosorbent assay kits (Linco Research, USA).

\section{RNA extraction and real-time polymerase chain reaction}

Total RNA from the tissues was extracted with TriReagent (Sigma, St. Louis, MO, USA), and its concentration was determined from absorbance at $260 \mathrm{~nm}$.

The TLR4 and AdipoR1 mRNA from RET, soleus and EDL were quantified by real-time polymerase chain reaction. RNA samples were previously treated with DNAse (DNA-free, Ambion, Austin, TX, USA). One microgram of each sample was reverse transcribed using an M-MLV Reverse Transcriptase kit (Promega, Madison, WI, USA), and cDNA was synthesized in a final volume of $50 \mu \mathrm{L}$. Relative levels of TLR4 and AdipoR1 mRNA were quantified in real time, using a SYBR Green primer in an ABI Prism 7500 Sequence Detector (both from Applied Biosystems, Foster City, CA, USA). Relative levels of the housekeeping gene hypoxanthine phosphoribosyltransferase were measured. The primers used were: AdipoR1 5'-CTT CTA CTG CTC CCC ACA GC-3' (sense) and 5'-TCC CAG GAA CAC TCC TGC TC-3' (antisense); and TLR-4 5'-GCATCATCTTCATTGTCCTTGAGA-3' (sense) and 5'-CTACCTT TTCGGAACTTAGGTCTACT-3' (antisense); and hypoxanthine phosphoribosyltransferase: 5'-CTCATGGA CTGATTATGGACAGGA-3' (sense) and 5'-GCAGGT CAGCAAAGAACTTATAGC-3' (antisense).

Results were obtained using Sequence Detector software (Applied Biosystems) and are expressed as a relative increase, using the method of $2^{-\Delta \Delta C t}$ described by Livak and Schmittgen [31].

\section{Protein analysis by Western Blotting}

After euthanasia, the RET, soleus and EDL muscle were rapidly removed, homogenized in $1.0 \mathrm{ml}$ extraction buffer (100 mM Trizma, 1\% SDS, $100 \mathrm{mM}$ sodium pyrophosphate, $100 \mathrm{mM}$ sodium fluoride, $10 \mathrm{mM}$ EDTA and $10 \mathrm{mM}$ sodium orthovanadate) and boiled for $10 \mathrm{~min}$. The extracts were then centrifuged at 12,000 $\mathrm{rpm}$ at $4^{\circ} \mathrm{C}$ for $40 \mathrm{~min}$ to remove the insoluble material. Protein determination in the supernatants was performed by the Bradford dye method using the Bio-Rad reagent (Bio-Rad Laboratories, Hercules, CA, USA). The proteins were treated with Laemmli sample buffer containing dithiothreitol and boiled for $5 \mathrm{~min}$ before loading onto $8 \%$ SDS-PAGE in a Bio-Rad miniature slab gel apparatus.

Electrotransfer of proteins from the gel to the nitrocellulose was performed for $1 \mathrm{~h}$ at $120 \mathrm{~V}$ (constant) in a BioRad miniature transfer apparatus. Nonspecific protein binding to the nitrocellulose was reduced by pre-incubation for $1 \mathrm{~h}$ at $22^{\circ} \mathrm{C}$ in blocking buffer (5\% non-fat dry milk, $10 \mathrm{mM}$ Tris, $150 \mathrm{mM} \mathrm{NaCl}$ and $0.02 \%$ Tween 20). The nitrocellulose membranes were incubated overnight at $4^{\circ} \mathrm{C}$ with antibodies against TLR4, TRAF6, AdipoR1 and $\alpha$-Tubulin obtained from Santa Cruz Biotechnology (Santa Cruz, CA, USA), diluted in blocking buffer combined with $1 \%$ bovine serum albumin (BSA) and then washed for $30 \mathrm{~min}$ in blocking buffer without BSA. The blots were subsequently incubated with a peroxidase-conjugated secondary antibody for $1 \mathrm{~h}$ at $22^{\circ} \mathrm{C}$ and processed for enhanced chemiluminescence to visualize the immunoreactive bands. Band intensities were quantificated by optical densitometry (Scion Image-Release Beta 3b, NIH, USA) of the developed autoradiographs.

\section{Statistical analysis}

All results are presented as mean \pm standard error of the mean. Statistical significances of the differences between the means of the two groups of samples were assessed using Student's $t$ test. Differences were considered to be statistically significant at $P<0.05$. 


\section{Results}

Body weight of the pups did not differ between the $\mathrm{C}$ and $\mathrm{T}$ groups at $21 \mathrm{~d}$ of life. However, the $\mathrm{T}$ diet promoted a significant increase in RET relative weight and in carcass lipid content $(\mathrm{p}<0.054)$ with no difference in carcass protein content. Also, $\mathrm{T}$ diet increased serum concentrations of triacylglycerols, total cholesterol and insulin (Table 2).

\section{Adipo-R1 gene and protein expression}

Adipo-R1 mRNA levels in the RET and EDL of group T were 2 and 2.75 times higher than in group $C$, respectively (Figure 1A, E). In contrast, in soleus muscle Adipo R1 mRNA levels were 45\% lower in group T (Figure 1C). The Adipo R1 protein expression was lower in RET and higher in EDL of $\mathrm{T}$ group than $\mathrm{C}$ (Figure 1B, F, respectively). Quantification of Adipo-R1 in soleus produced similar figures in both groups (Figure 1D).

\section{TLR-4 gene and protein expression}

TLR-4 mRNA levels in the soleus of group T were 1.6 times higher than in group C (Figure 2E). Quantification of TLR-4 mRNA in RET and EDL produced similar figures in both groups (Figure 2A, C, respectively). The ingestion of diet containing trans fatty acid during lactation and gestation did not modified the TLR-4 protein content in all studied tissues from pups with $21 \mathrm{~d}$ of life (Figure 2B, D, F).

\section{TRAF- 6 protein expression}

The ingestion of hydrogenated vegetable fat during gestation and lactation caused an increase in TRAF- 6 protein

Table 2 Body weight (g), retroperitoneal white adipose tissue (RET), soleus and EDL muscle relative weights (g/ $100 \mathrm{~g} \mathrm{~b}$. w.), carcass protein and fat content (g per $100 \mathrm{~g}$ of body weight), serum glucose, triacylglycerols, cholesterol, HDL cholesterol, insulin, and adiponectin in the $C$ and $T$ groups.

\begin{tabular}{lcc}
\hline & Control & Trans \\
\hline Body weight $(\mathrm{g})$ & $41.55 \pm 2.49$ & $40.50 \pm 1.79$ \\
\hline RET relative weight $(\mathrm{g} / \mathrm{100 \textrm {g }})$ & $0.21 \pm 0.03$ & $0.27 \pm 0.01^{*}$ \\
\hline Soleus relative weight $(\mathrm{g} / \mathrm{100 \textrm {g }})$ & $0.09 \pm 0.006$ & $0.09 \pm 0.003$ \\
\hline EDL relative weight $(\mathrm{g} / \mathrm{100 \textrm {g }})$ & $0.09 \pm 0.007$ & $0.10 \pm 0.004$ \\
\hline Carcass lipid content $(\mathrm{g} / \mathrm{100g})$ & $3.98 \pm 0.34$ & $4.61 \pm 0.228$ \\
\hline Carcass protein content & $10.38 \pm 1.12$ & $11.536 \pm 0.29$ \\
\hline Triacylglycerol $(\mathrm{mg} / \mathrm{dL})$ & $201.82 \pm 20.75$ & $456.93 \pm 25.50^{*}$ \\
\hline Glucose $(\mathrm{mg} / \mathrm{dL})$ & $90.46 \pm 3.42$ & $99.77 \pm 3.43$ \\
\hline Total cholesterol $(\mathrm{mg} / \mathrm{dL})$ & $146.86 \pm 3.4$ & $171.22 \pm 7.47^{*}$ \\
\hline HDL-cholesterol $(\mathrm{mg} / \mathrm{dL})$ & $34.49 \pm 1.68$ & $38.46 \pm 6.93$ \\
\hline Adiponectin $(\mathrm{\mu g} / \mathrm{mL})$ & $9.87 \pm 1.35$ & $11.52 \pm 1.94$ \\
\hline Insulin & $0.63 \pm 0.05$ & $1.07 \pm 0.19^{*}$ \\
\hline
\end{tabular}

Data are means \pm SEMs of 10 determinations/group. ${ }^{*} P<0.05$ versus $C$. expression in RET of 21 day old pups (Figure 3A). However, the TRAF- 6 protein expression was similar in soleus and EDL between $\mathrm{C}$ and $\mathrm{T}$ groups (Figure $3 \mathrm{~B}, \mathrm{C}$ ).

\section{Discussion}

In this study, maternal ingestion of hydrogenated vegetable fat rich in TFAs during gestation and lactation altered the blood lipid profiles, increased insulin serum levels accompanied by a decrease in Adipo R 1 protein expression and increase in TRAF-6 protein expression in retroperitoneal adipose tissue, which could contributed for insulin resistance and the dyslipidemia observed in their 21-d-old offspring.

The body weight of offspring exposed to maternal TFAs was similar to those of the $\mathrm{C}$ group, confirming our previous findings [9,32]. Also, Colandré et al. [33] found that the ingestion of TFAs by adult rats for $30 \mathrm{~d}$ failed to change weight gain. On the other hand, the ingestion of TFA reduced body weight gain in 90-d- old offspring [34] or increased this parameter in 14- and 45-d-old rats exposed during lactation and after weaning to a normolipidic diet of which $7 \%$ was hydrogenated fat [35]. These results suggest that the effect on body weight of dietary TFAs depends on the period of life that the animal is exposure.

In the present study we analyzed the lipid content in the carcass without any viscera and visceral fat pad, just to quantify the subcutaneous fat pad which was similar between $\mathrm{T}$ and $\mathrm{C}$ groups. Previously, we have found an increase in carcass total lipid content (with all fat pads) in group $\mathrm{T}$ comparing to $\mathrm{C}$ [9]. In fact, in the present study the RET relative weight was higher in $\mathrm{T}$ than $\mathrm{C}$ group. Taken all together these results demonstrated that the maternal ingestion of hydrogenated vegetable fat rich in TFAs during gestation and lactation promoted an increase in visceral fat pad accumulation in the 21- $d$-old offspring. It could be suggested that this occur, at least partially, by a decrease in adiponectin effect on RET since the adipoR1 was lower in retroperitoneal adipose tissue from $\mathrm{T}$ than $\mathrm{C}$. It has been shown that adiponectin attenuates acetyl-CoA carboxylase activity reducing lipid synthesis and indirectly enhances fatty acid oxidation by blocking the production of malonyl-CoA [36]. In this sense, Silva et al. [35] studying the effects of TFA ingestion just during lactation, verified increased in de novo lipogenesis rates and lipid contents in the EPI adipose tissue of offspring aged $45 \mathrm{~d}$.

In accordance to our formerly report [9], feeding lactating rats with a diet $7 \%$ of which was made up of hydrogenated vegetable fat promoted an increase in serum triacylglycerol and total cholesterol levels. TFAs ingestion during lactation led to increased milk content of, long-chain saturated fatty acids, and total lipid, and decreased polyunsaturated fatty acids [37], and TFAs and saturated fatty acids increased 


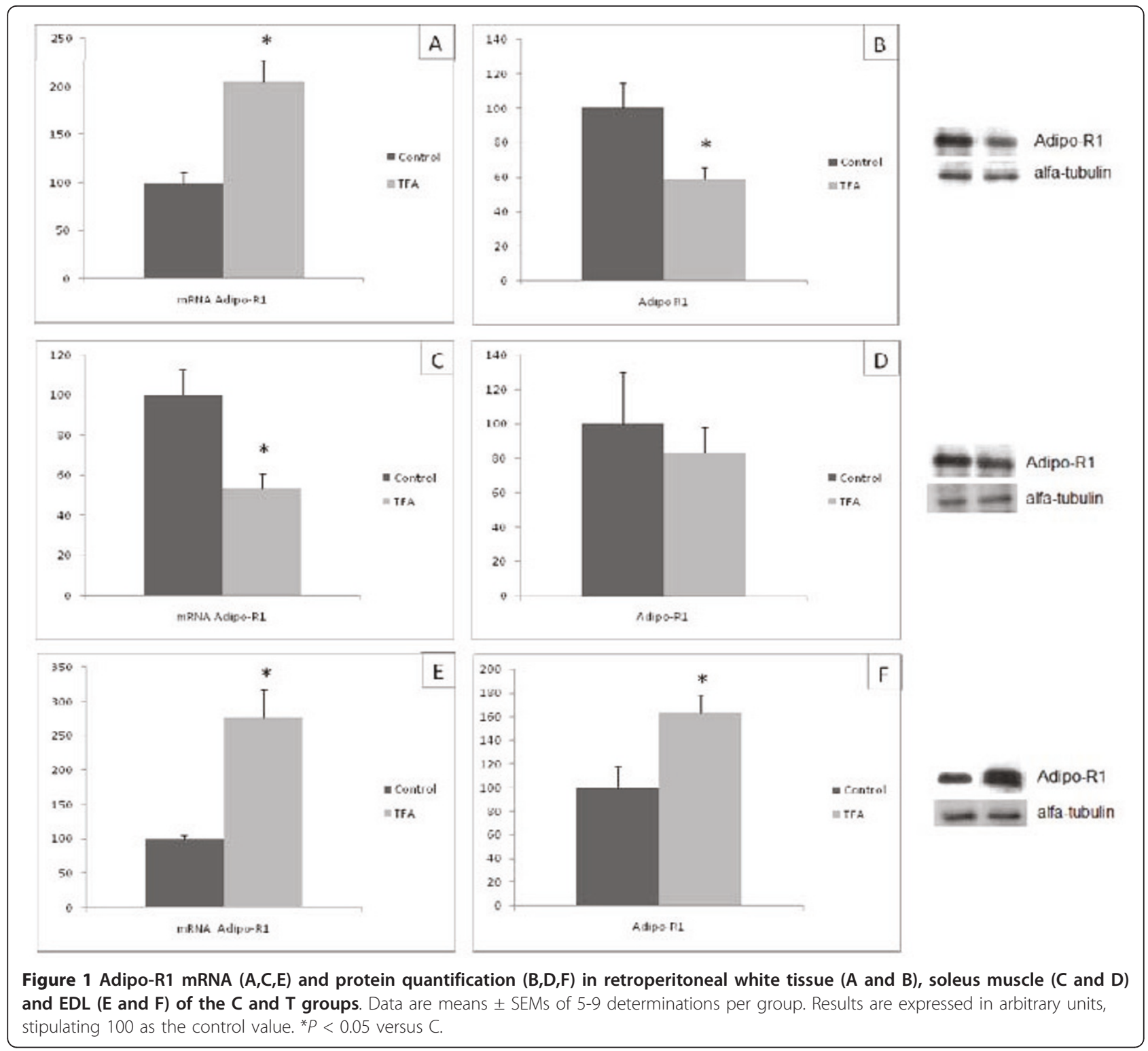

VLDL secretion [38]. Ng et al. [39], reported that triacylglycerol concentration is inversely correlated with adiponectin plasma concentration. Then, it is possible that the decrease in adiponectin receptor in RET of T group could be an important mechanisms to contributed to the high serum triacylglycerol and cholesterol levels in this group. A similar effect was induced by administration of TNF- $\alpha$ to hamsters [40]. Maternal ingestion of hydrogenated vegetable fat rich in TFAs during gestation and lactation elevated TNF- $\alpha$ gene expression in RET of 21-d- old offspring, and it has been previously shown that TNF- $\alpha$ gene expression in adipose tissue correlates with circulating TNF- $\alpha$ levels [41]. Thus, high TNF- $\alpha$ activity is likely to have contributed to dyslipidemia observed in $\mathrm{T}$ group. Alteration of plasma lipoprotein profile, with increased risk of cardiovascular diseases, decreased insulin sensitivity, and higher risk of type 2 diabetes, has been reported to follow the long-term intake of TFAs [16,42-44]. However, other studies have failed to find an effect of TFAs hyperinsulinemia and insulin resistance $[9,45,46]$.

In the present study we have shown that maternal ingestion of trans fatty acid caused an increase in insulin serum level in 21-d-old offspring accompanied by an increase in TRAF- 6 and decrease in AdipoR1 protein expression in RET regardless of a decrease in AdipoR1 mRNA level. Recent study reported decreased in AdipoR1 protein levels in monocytes from type 2 diabetic subjects, while AdipoR1 mRNA content was actually increased, reinforcing that the changes in protein do not always occur in parallel to change in mRNA levels [47]. 

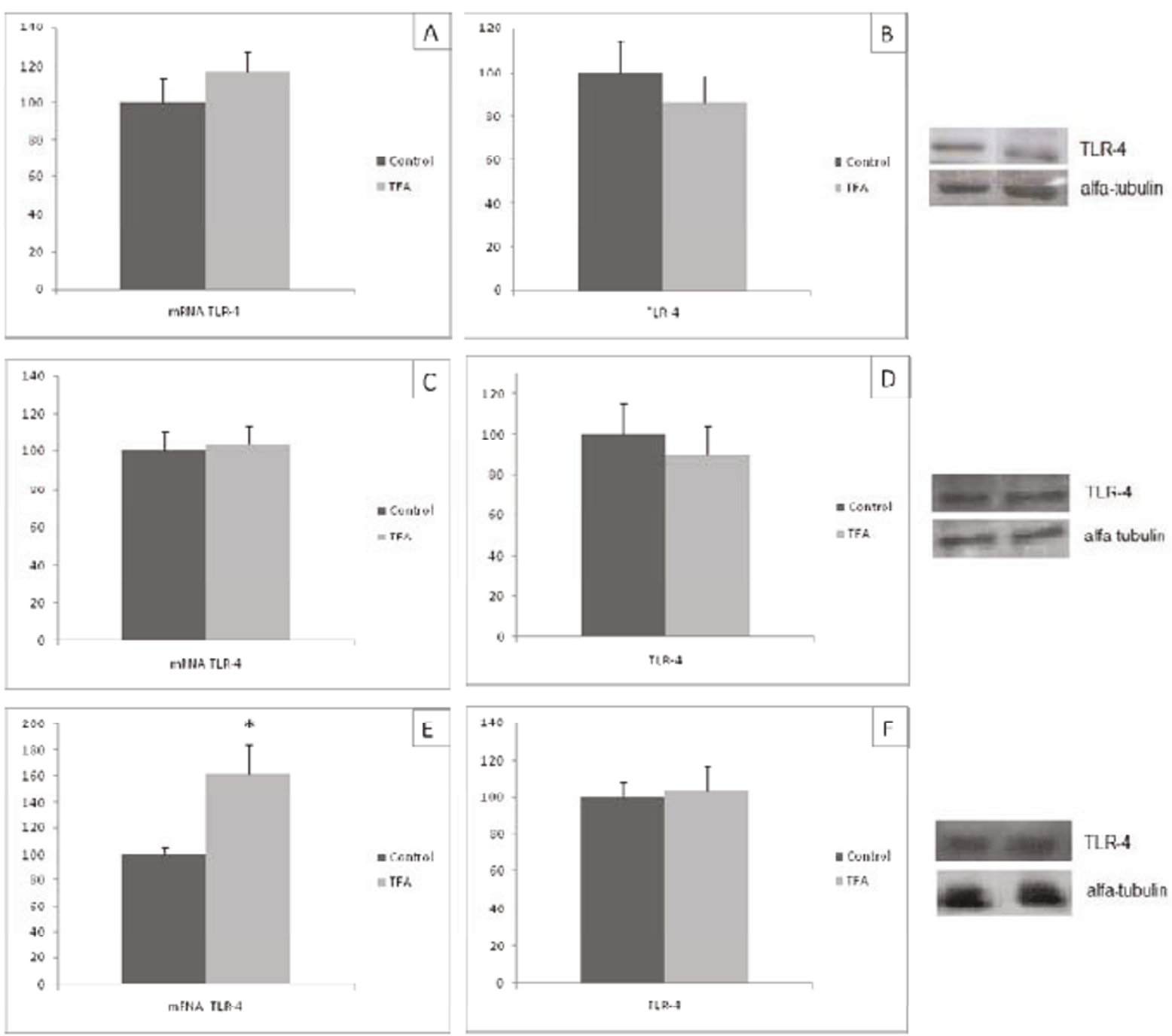

Figure 2 TLR-4 mRNA ( $A, C, E)$ and protein quantification (B,D,F) in retroperitoneal white tissue $(A$ and $B)$, soleus muscle (C and $D)$ and EDL (E and F) of the $C$ and T groups. Data are means \pm SEMs of 5-9 determinations per group. Results are expressed in arbitrary units, stipulating 100 as the control value. ${ }^{*} P<0.05$ versus $C$.

Previously, it has been shown an increase in protein expression of TLR-2, MyD88, and TRAF6 as well as NF- $\kappa \mathrm{B}$ in human adipose tissue in states of obesity and diabetes mellitus type 2 [48]. These results suggested that the insulin resistance caused by trans fat acid ingestions could be related to the induced innate immune cascade in adipose tissue promoting an increase in proinflammatory adipokines expression, as reported by our group $[9,34]$ and reducing the adiponectin effect by reducing the adipoR1 protein expression. Activation of proinflammatory adipokines in adipose tissue is coordinated through NF- $\kappa \mathrm{B}$, a key transcription factor in the inflammatory cascade. The increase in TRAF-6, observed in the present study contributes in inflammatory responses leading, probably, the activation of the
NF- $\kappa$ B pathway. We did not measure the NF-kB DNA binding, however the increase in TRAF- 6 normally is related to activation of NF- $\kappa$ B pathway [49].

Creely et al [48] observed a positive correlation between insulin serum concentration and endotoxinemia. Then it is possible to suggest that the hyperinsulinemia, present in TFA group, associated to the effect of fatty acids in the intestinal microbial composition [50] modified the intestinal permeability elevating lipopolysaccharides activating the inflammatory cascade, promoting an increase in TRAF-6.

The TFA ingestion during gestation and lactating caused a different effect on oxidative muscle (soleus) and glycolytic muscle (EDL). Different type of fiber shows different response, for instance expression of TNF- $\alpha$ has 

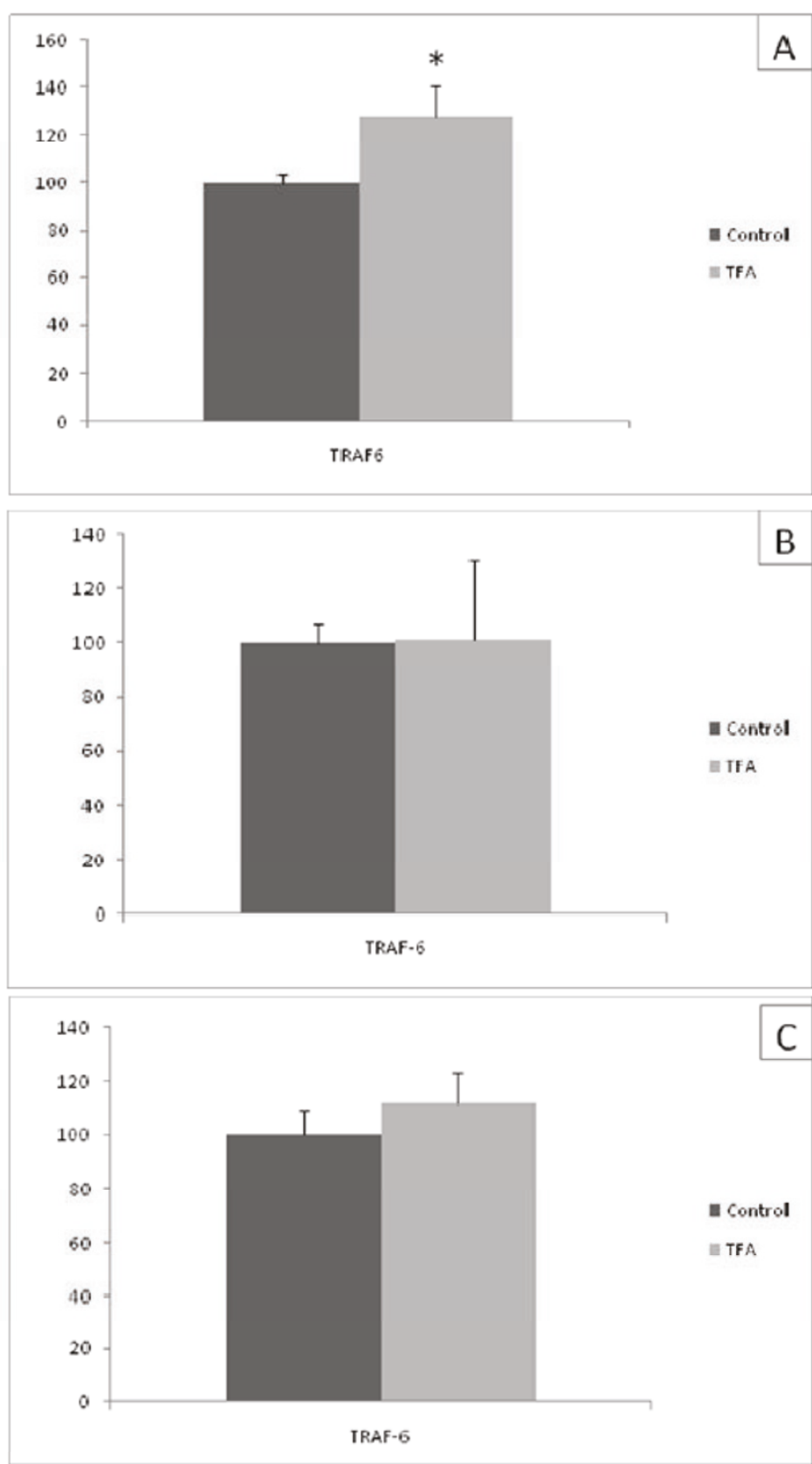
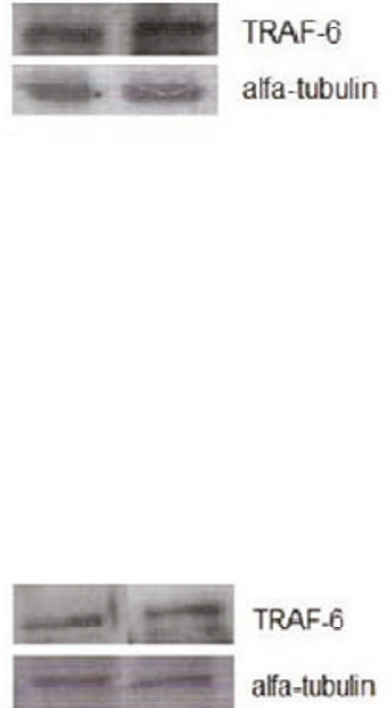

alfa-tubulin

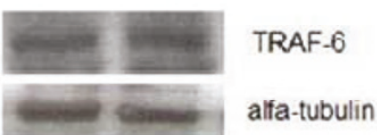

alfa-tubulin

Figure 3 TRAF-6 protein quantification in retroperitoneal white tissue (A), soleus muscle (B) and EDL (C) of the C and T groups. Data are means \pm SEMs of 5-9 determinations per group. Results are expressed in arbitrary units, stipulating 100 as the control value. ${ }^{*} P<0.05$ versus $C$.

been reported in glycolytic fibers from sedentary healthy subjects, but not in oxidative fibers [51].

The TFA did not modify the parameters analyzed in soleus muscle, however promoted an increase in AdipoR1 protein expression and in TLR-4 gene expression in EDL of 21-d-offspring. As previously reported AdipoR1 protein content in soleus muscle was not affected either by saturated or polyunsaturated fatty acid rich diet [52]. Despite of several studies demonstrated that fatty acid rich diet could promote an insulin resistance in muscle, our results suggest that the change in AdipoR1 protein in muscle is not important for impairing inflammatory response in muscle or that the TFA during gestation and lactation caused more important modification in adipose tissue than muscle related to the inflammatory process.

In conclusion the present study confirmed that maternal ingestion of hydrogenated vegetable fat rich in TFAs 
during gestation and lactation altered the blood lipid profiles of 21-d old-offsprig. Also, demonstrated that caused an increase in insulin serum levels accompanied by a decrease in Adipo R1 protein expression and increase in TRAF- 6 protein expression in retroperitoneal adipose tissue, but not in skeletal muscle, which could contributed for hyperinsulinemia and dyslipidemia observed in their 21-d-old offspring.

\section{Acknowledgements}

This research was supported by CAPES (Coordenação de Aperfeiçoamento de Pessoal de Nível Superior), CNPq (Conselho Nacional de Desenvolvimento Científico e Tecnológico) and FAPESP (Fundação de Amparo à Pesquisa do Estado de São Paulo, n²008/57722-0). The authors gratefully acknowledge the invaluable assistance of Mauro Cardoso Pereira for the animal care.

\section{Author details}

${ }^{1}$ Departamento Fisiologia, Disciplina de Fisiologia da Nutrição, Universidade Federal de São Paulo, São Paulo, SP, Brasil. '2Departamento de Ciências da Saúde, Universidade Federal de São Paulo, Santos, SP, Brazil.

\section{Authors' contributions}

JOO designed the study, carried out the experiments, performed the statistical analysis and drafted the manuscript.

LMO participated in the design of the study helped to carried out the experiments.

ACLH helped to carried out the experiments.

$\mathrm{CB}$ helped to carried out the experiments.

EBR revised and helped to draft the manuscript.

CON help to conceive the study, participated in its design, and helped to draft the manuscript.

LPP conceived of the study, participated in its design, coordination and helped to draft the manuscript.

All authors read and approved the final manuscript

\section{Competing interests}

The authors declare that they have no competing interests.

Received: 7 December 2010 Accepted: 25 January 2011

Published: 25 January 2011

\section{References}

1. Godfrey KM, Barker DJ: Fetal programming and adult health. Public Health Nutr 2001, 4:611-624.

2. Morley R, Dwyer T: Fetal origins of adult disease? Clin Exp Pharmacol Physiol 2001, 28:962-6.

3. Gillman MW: Epidemiological challenges in studying the fetal origins of adult chronic disease. Int F Epidemiol 2002, 31:294-299.

4. Godfrey KM, Forrester T, Barker DJ, Jackson AA, Landman JP, Hall JS, Cox V, Osmond C: Maternal nutritional status in pregnancy and blood pressure in childhood. Br J Obstet Gynaecol 1994, 101(5):398-403.

5. Godfrey KM, Breier BH, Cooper C: Constraint of the materno-placental supply of nutrients: Causes and consequences. In Fetal Programming. Edited by: O'Brien PMS, Wheeler T, Barker DJP. London, UK: Royal College of Obstetricians and Gynaecologists; 1999:283-298.

6. Mi J, Law C, Zhang KL, Osmond C, Stein C, Barker D: Effects of infant birthweight and maternal body mass index in pregnancy on components of the insulin resistance syndrome in China. Ann Intern Med 2000, 132(4):253-60.

7. Herrera E: Implications of dietary fatty acids during pregnancy on placental, fetal and postnatal development-a review. Placenta 2002, , Suppl A: S9-19.

8. Ibrahim A, Natrajan S, Ghafoorunissa R: Dietary trans-fatty acids alter adipocyte plasma membrane fatty acid composition and insulin sensitivity in rats. Metab Clin Exp 2005, 54(2):240-6.

9. Pisani LP, Oyama LM, Bueno AA, Biz C, Albuquerque KT, Ribeiro EB, Oller do Nascimento CM: Hydrogenated fat intake during pregnancy and lactation modifies serum lipid profile and adipokine mRNA in 21-day-old rats. Nutrition 2008, 24(3):255-61.

10. Hotta K, Funahashi T, Arita Y, Takahashi M, Matsuda M, Okamoto Y, Iwahashi H, Kuriyama H, Ouchi N, Maeda K, Nishida M, Kihara S, Sakai N, Nakajima T, Hasegawa K, Muraguchi M, Ohmoto Y, Nakamura T, Yamashita S, Hanafusa T, Matsuzawa Y: Plasma concentrations of a novel, adipose-specific protein, adiponectin, in type 2 diabetic patients. Arterioscler Thromb Vasc Biol 2000, 20(6):1595-9.

11. Diez JJ, Iglesias P: The role of the novel adipocyte-derived hormone adiponectin in human disease. Eur J Endocrinol 2003, 148(3):293-300.

12. Prins JB: Adipose tissue as an endocrine organ. Best Pract Res Clin Endocrinol Metab 2002, 16(4):639-51.

13. Judd JT, Baer DJ, Clevidence BA, Muesing RA, Chen SC, Weststrate JÁ, Meijer GW, Wittes J, Lichtenstein AH, Vilella-Bach M, Schaefer EJ: Effects of margarine compared with those of butter on blood lipid profiles related to cardiovascular disease risk factors in normolipemic adults fed controlled diets. American Journal Clinical Nutrition 1998, 68:768-777.

14. Hu FB, Dam RM, Liu S: Diet and risk of type II diabetes: the role of types of fat and carbohydrate. Diabetologia 2001, 44:805-817.

15. Lichtenstein $A H$, Jauhiainen M, McGladdery S, Ausman LM, Jalbert SM, Vilella-Bach M, Ehnholm C, Frohlich J, Schaefer EJ: Impact of hydrogenated fat on high density lipoprotein subfractions and metabolism. Journal of Lipid Research 2001, 42:597-604.

16. Lichtenstein AH, Erkkila AT, Lamarche B, Schwab US, Jalbert SM, Ausman LM: Influence of hydrogenated fat and butter on CVD risk factors: remnant-like particles, glucose and insulin, blood pressure and C-reactive protein. Atherosclerosis 2003, 171:97-107.

17. Berdanier CD, Symposium: Nutritional and Metabolic Diversity: Understanding the Basis of Biologic Variance in the Obesity/Diabetes/Cardiovascular Disease Connection. American Society for Nutritional Sciences 2001, 344S-353S.

18. Matthan NR, Cianflone $K$, Lichtenstein AH, Ausman LM, Jauhiainen M, Jones PJH: Hydrogenated fat consumption affects acylation-stimulating protein levels and cholesterol esterification rates in moderately hypercholesterolemic women. Journal of Lipid Research 2001, 42:1841-1848.

19. Han SN, Leka LS, Lichtenstein AH, Ausman LM, Schaefer EJ, Meydani SN: Effect of hydrogenated and saturated, relative to polyunsaturated, fat on immune and inflammatory responses of adults with moderate hypercholesterolemia. J Lipid Res 2002, 43(3):445-52.

20. Grundy SM, Abate N, Chandalia M: Diet composition and the metabolic syndrome: what is the optimal fat intake? Am J Med 2002, 25S-29S.

21. McFarlin BK, Flynn MG, Campbell WW, Stewart LK, Timmerman KL: TLR4 is lower in resistance-trained older women and related to inflammatory cytokines. Med Sci Sports Exerc 2004, 36(11):1876-83.

22. Gleeson M, McFarlin B, Flynn M: Exercise and Toll-like receptors. Exerc Immunol Rev 2006, 12:34-53.

23. Tsukumo DM, Carvalho-Filho MA, Carvalheira JB, Prada PO, Hirabara SM, Schenka AA, Araújo EP, Vassallo J, Curi R, Velloso LA, Saad MJ: Loss-offunction mutation in Toll-like receptor 4 prevents diet-induced obesity and insulin resistance. Diabetes 2007, 56(8):1986-98.

24. Poltorak A, He X, Smirnova I, Liu MY, Van Huffel C, Du X, Birdwell D, Alejos E, Silva M, Galanos C, Freudenberg M, Ricciardi-Castagnoli P, Layton B, Beutler B: Defective LPS signaling in C3H/HeJ and C57BL/ 10SCCr mice: mutations in TLR4 gene. Science 1998, 282:2085-2088.

25. Lee JY, Ye J, Gao Z, Youn HS, Lee WH, Zhao L, Sizemore N, Hwang DH: Reciprocal modulation of Toll-like receptor-4 signaling pathways involving MyD88 and phosphatidylinositol 3-kinase/AKT by saturated and polyunsaturated fatty acids. J Biol Chem 2003, 278:37041-37051.

26. O'Neill LA: How Toll-like receptors signal: what we know and what we don't know. Curr Opin Immunol 2006, 18:3-9.

27. Tsan MF: Toll-like receptors, inflammation and cancer. Semin Cancer Biol 2006, 16:32-37.

28. Reeves PG: Components of the AIN-93 diets as improvements in the AIN-76A diet. J Nutr 1997, 127(5 Suppl):838S-841S.

29. Oller do Nascimento CM, Williamson DH: Evidence for conservation of dietary lipid in the rat during lactation and the immediate period after removal of the litter. Biochem J 1986, 239:233-236.

30. Lowry $\mathrm{OH}$, Rosebrough NJ, Farr AL, Randall RJ: Protein measurement with the Folin phenol reagent. J Biol Chem 1951, 193(1):265-75.

31. Livak KJ, Schmittgen TD: Analysis of relative gene expression data using real-time quantitative PCR and the 2(-Delta Delta C(T)) Method. Methods 2001, 25(4):402-8. 
32. Albuquerque KT, Sardinha FL, Telles MM, Watanabe RL, Nascimento CM, Tavares do Carmo MG, Ribeiro EB: Intake of trans fatty acid-rich hydrogenated fat during pregnancy and lactation inhibits the hypophagic effect of central insulin in the adult offspring. Nutrition 2006, 22(7-8):820-9.

33. Colandré ME, Diez RS, Bernal CA: Metabolic effects of trans fatty acids on an experimental dietary model. Br J Nutr 2003, 89(5):631-9.

34. Pisani LP, Oller do Nascimento CM, Bueno AA, Biz C, Albuquerque KT, Ribeiro $E B$, Oyama $L M$ : Hydrogenated fat diet intake during pregnancy and lactation modifies the PAl-1 gene expression in white adipose tissue of offspring in adult life. Lipids Health Dis 2008, 7:13.

35. Silva AP, Guimarães DE, Mizurini DM, Maia IC, Ortiz-Costa S, Sardinha FL, do Carmo MG: Dietary fatty acids early in life affect lipid metabolism and adiposity in young rats. Lipids 2006, 41:535-541.

36. Rogers CQ, Ajmo JM, You M: Adiponectin and alcoholic fatty liver disease. IUBMB Life 2008, 60(12):790-7.

37. Assumpção RP, dos Santos FD, Andrade PMM, Barreto GF, das Carmo MGT: Effect of variation of trans-fatty acid in lactating rats' diet on lipoprotein lipase activity in mammary gland, liver, and adipose tissue. Nutrition 2004, 20:806-811.

38. Wijendran V, Pronczuk A, Bertoli C, Hayes KC: Dietary trans-18:1 raises plasma triglycerides and VLDL cholesterol when replacing either $16: 0$ or 18:0 in gerbils. J Nutr Biochem 2003, 14:584-590.

39. Ng TW, Watts GF, Farvid MS, Chan DC, Barrett PH: Adipocytokines and VLDL metabolism: independent regulatory effects of adiponectin, insulin resistance, and fat compartments on VLDL apolipoprotein B-100 kinetics. Diabetes 2005, 54:795-802.

40. Hardardorttir I, Moser AH, Memon R, Grunfeld C, Feingold KR: Effects of TNF, IL-1, and the combination of both cytokines on cholesterol metabolism in Syrian hamsters. Lymphokine Cytokine Res 1994, 13:161-166.

41. Zhao SP, Wu ZH, Wu J, Hong SC, Deng P: Effect of atorvastatin on tumor necrosis factor alpha serum concentration and mRNA expression of adipose in hypercholesterolemic rabbits. J Cardiovasc Pharmacol 2005, 46:185-189.

42. Lichtenstein AH, Ausman LA, Jalbert SM, Schaefer EJ: Effects of different forms of dietary hydrogenated fats on serum lipoprotein cholesterol levels. N Engl J Med 1999, 340:1933-1940.

43. Salmeron J, Hu FB, Manson JE, Stampfer MJ, Colditz GA, Rimm EB: Dietary fatty intake and risk of type 2 diabetes in women. Am J Clin Nutr 2001, 73:1019-1026.

44. Ibrahim A, Natrajan S, Ghafoorunissa R: Dietary trans-fatty acids alter adipocyte plasma membrane fatty acid composition and insulin sensitivity in rats. Metab Clin Exp 2005, 54(2):240-6.

45. Lovejoy JC, Smith SR, Champagne CM, Marlene MM, Lefevre M, DeLany JP: Effects of diets enriched in saturated (palmitic), monounsaturated (oleic), or trans (elaidic) fatty acids on insulin sensitivity and substrate oxidation in healthy adults. Diabetes Care 2002, 25:1283-1288.

46. Louheranta AM, Turpeinen AK, Vidgren HM, Schawab US, Uusitupa MI: A high-trans fatty acid diet and insulin sensitivity in young healthy women. Metabolism 1999, 48:870-875.

47. Weigert J, Neumeier M, Wanninger J, Wurm S, Kopp A, Schober F, Filarsky M, Schaffler A, Zeitoun M, Aslanidis C, Buechler C: Reduced response to adiponectin and lower abundance of adiponectin receptor proteins in type 2 diabetic monocytes. FEBS Lett 2008, 582:1777-1782.

48. Creely SJ, McTernan PG, Kusminski CM, Fisher M, Da Silva NF, Khanolkar M, Evans M, Harte AL, Kumar S: Lipopolysaccharide activates an innate immune system response in human adipose tissue in obesity and type 2 diabetes. Am J PhysiolEndocrinol Metab 2007, 292(3):E740-7.

49. Landström M: The TAK1-TRAF6 signalling pathway. The International Journal of Biochemistry \& Cell Biology 2010, 42(5):585-589.

50. Cani PD, Bibiloni R, Knauf C, Waget A, Neyrinck AM, Delzenne NM, Burcelin R: Changes in gut microbiota control metabolic endotoxemiainduced inflammation in high-fat diet-induced obesity and diabetes in mice. Diabetes 2008, 57(6):1470-81.

51. Plomgaard $P$, Penkowa $M$, Pedersen BK: Fiber type specific expression of TNF-alpha, IL-6 and IL-18 in human skeletal muscles. Exerc Immunol Rev 2005, 11:53-63.

52. Mullen KL, Tishinsky JM, Robinson LE, Dyck DJ: Skeletal muscle inflammation is not responsible for the rapid impairment in adiponectin response with high-fat feeding in rats. Am J Physiol Regul Integr Comp Physiol 2010, 299(2):R500-8.

\section{doi:10.1186/1476-511X-10-22}

Cite this article as: de Oliveira et al: Hydrogenated fat intake during pregnancy and lactation caused increase in TRAF- 6 and reduced AdipoR1 in white adipose tissue, but not in muscle of 21 days old offspring rats. Lipids in Health and Disease 2011 10:22.

\section{Submit your next manuscript to BioMed Central and take full advantage of:}

- Convenient online submission

- Thorough peer review

- No space constraints or color figure charges

- Immediate publication on acceptance

- Inclusion in PubMed, CAS, Scopus and Google Scholar

- Research which is freely available for redistribution

Submit your manuscript at www.biomedcentral.com/submit
Biomed Central 